Portland State University

PDXScholar

4-1-2007

\title{
Pointing Users Toward Citation Searching: Using Google Scholar and Web of Science
}

Robert Schroeder

Portland State University, schroedr@pdx.edu

Follow this and additional works at: https://pdxscholar.library.pdx.edu/ulib_fac

Part of the Library and Information Science Commons

Let us know how access to this document benefits you.

Citation Details

Schroeder, R. (2007). Pointing users toward citation searching: using Google Scholar and Web of Science. Portal: Libraries \& The Academy, 7(2), 243-248.

This Article is brought to you for free and open access. It has been accepted for inclusion in Library Faculty Publications and Presentations by an authorized administrator of PDXScholar. Please contact us if we can make this document more accessible: pdxscholar@pdx.edu. 


\section{Pointing Users Toward Citation Searching: Using Google Scholar and Web of Science}

\section{Robert Schroeder}

Much has been written about citation indexing since Eugene Garfield's seminal article in 1955, "Citation Indexes for Science: A New Dimension in Documentation through Association of Ideas."1 In the 1960s, the discussion was about Garfield's Science Citation Index and later its successor, Web of Science. For almost half a century, these were the only available tools for tracing scholarly discourse forward in time. Now there are two new tools. SCOPUS is a commercial product from Elsevier and was launched in November 2004. Google Scholar also arrived on the scene in November 2004. Because Google Scholar is freely accessible from the Google site, students and faculty are finding and using it. They are beginning to ask librarians for their professional opinions of its efficacy. Practicing reference and instruction librarians need to understand the strengths of both Google Scholar and Web of Science so that they can appropriately recommend them for use by their patrons-whether they are undergraduates, graduate students, or faculty.

Since April 2005, 10 studies have been published that directly compare the citation features of Google Scholar to those of Web of Science. In an effort to better understand the advantages and disadvantages of these tools, the author undertook an investigation of this research. Although the parameters of the studies varied greatly with respect to the disciplines, dates, and sample sizes, analysis of these preliminary studies can help us gain an initial—albeit sketchy—impression of the relative strength and weakness of each service. The results of this effort are reported here as an informal meta-analysis, followed by some recommendations for utilizing these tools across a range of needs.

The coverage of each database is both overlapping and complementary. Web of Science is comprised of a known list of highly prestigious journals. The extent to which disciplines are covered is well known, but it is limited to these journal holdings. Although Google Scholar overlaps with Web of Science in some of its coverage, it also includes conference proceedings, books, preprints, and a variety of versions of articles available in open access databases and institutional repositories. Search results do, however, include many "false hits" —non-scholarly sources or titles that are similar to, but not 


\section{Table 1}

\section{Overview of the scope of the 10 studies}

\begin{tabular}{|c|c|c|}
\hline Researchers & Publication date & Nature and scope of citation research \\
\hline Belew $^{2}$ & April 2005 & 203 articles published by 6 cognitive scientists \\
\hline Bauer and Bakkalasi ${ }^{3}$ & September 2005 & $\begin{array}{l}\text { All of the articles published in 1985(41) and } 2000 \\
\text { (105) in the Journal of the American Society for Informa- } \\
\text { tion Science and Technology (JASIST) }\end{array}$ \\
\hline Jasco $(\mathrm{Web})^{4}$ & October (?) 2005 & Most cited article from The Scientist \\
\hline Jasco (Current Science) ${ }^{5}$ & November 2005 & $\begin{array}{l}\text { (A). Eugene Garfield's } 1955 \text { article "Citation Indexes } \\
\text { for Science" }\end{array}$ \\
\hline Jasco $(\mathrm{ICADL})^{6}$ & December 2005 & $\begin{array}{l}\text { (B). The } 30 \text { most cited articles from Current Science } \\
\text { All of the papers published in the Asian Pacific Journal } \\
\text { of Allergy and Immunology from the years } 1983 \text { to } 2000\end{array}$ \\
\hline
\end{tabular}

Noruzi $^{7} \quad$ December 2005

Pauly and Stergiou $\quad$ December 2005

(A). 1 article from the Journal of Documentation, "Infometric Analyses on the World Wide Web: Methodological Approaches to Webometrics"

(B). Keyword search for "webometics OR webometric" 114 articles from various scientific disciplines (mathematics, chemistry, physics, computing science, molecular biology, ecology, fisheries, oceanography, geosciences, economics, and psychology)

3 articles (one high, medium, and low cited) from 3 authors in each filed, plus 15 "highly cited articles"

Bakkalbasi, Bauer, June 2006 A random sample of articles from 22 journals in the fields of oncology and condensed matter physics from the years 1993 and 2003

Kousha and Thelwall ${ }^{10}$ June 2006 A sample of 1,650 articles from four social science and four science disciplines from 108 Open Access journals published in 2001

Yang and Meho ${ }^{11} \quad$ December 2006 109 publications of two Library and Information Scientists from 1980 to 2005 . The publications include many format types besides articles, such as conference papers, reports, books, book chapters, etc.

exact matches for, the target citation. These spurious links cause the researcher to spend much more time analyzing and evaluating the sources.

Date coverage is also complementary, with Web of Science consistently providing older articles. Google Scholar often returns more current results due to its ability to access early versions of works in progress and open access articles available on the Internet. Although the controlled vocabulary in Web of Science is less than perfect, it wins hands-down over Google Scholar, which is totally lacking in any of the finer points of indexing. 


\section{Table 2}

\section{Summary of positive and negative characteristics of Web of Science and Google Scholar from the 10 studies}

\begin{tabular}{cccc}
\hline & Web of Science & \multicolumn{2}{c}{ Google Scholar } \\
Positive & Negative & Positive & Negative \\
\hline
\end{tabular}

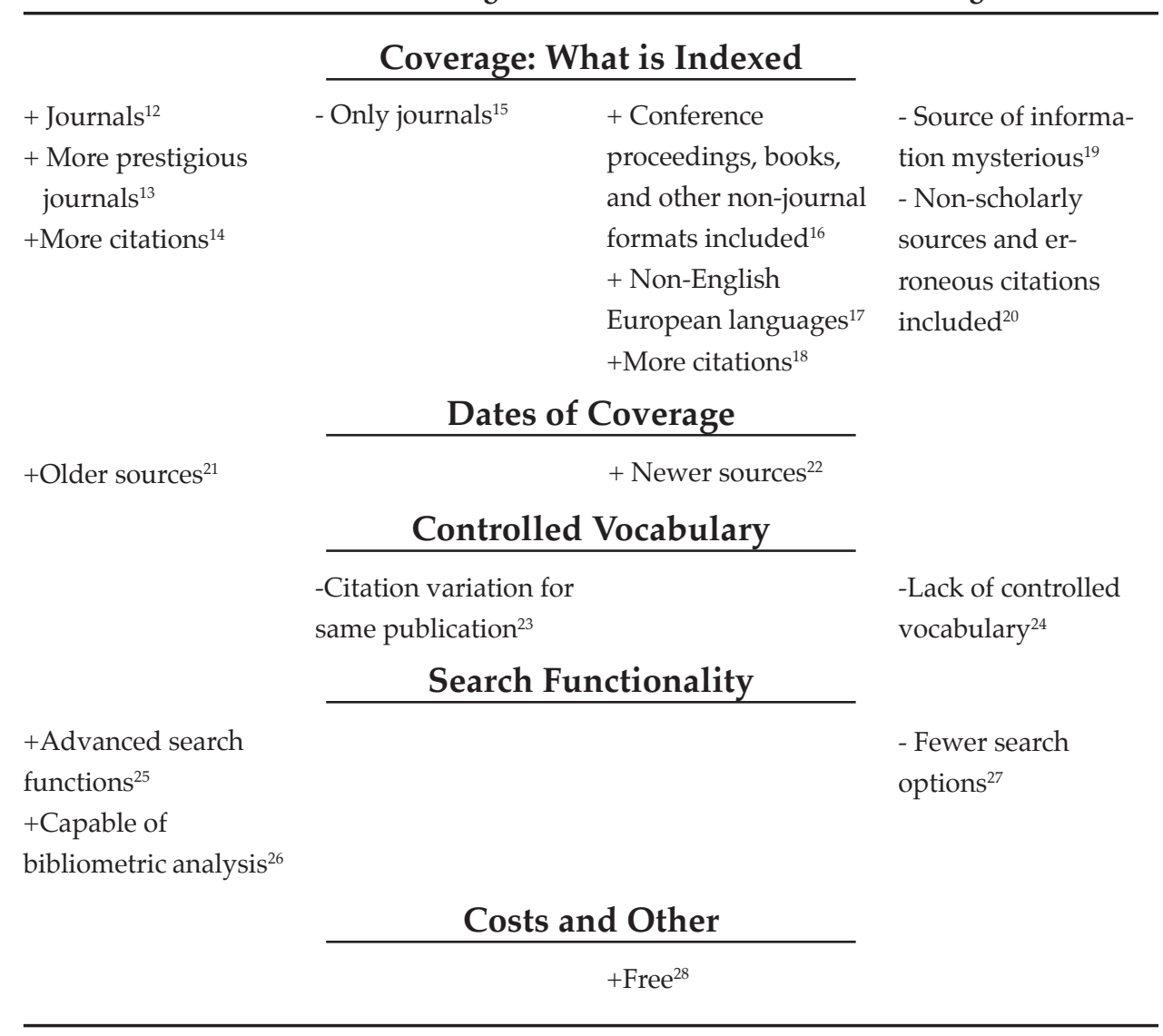

The findings from these initial studies suggest a variety of uses for both of the databases' citation features in academic reference and instruction. For instructing undergraduate students in the use of the "cited by" features, Google Scholar's lack of advanced search functions may actually be a boon. Most students today are familiar with the look and feel of the "one box searching" of Google. Having a similar uncluttered look, Google Scholar appears less intimidating to novice users, allowing them to focus on the concepts involved in citation searching and analysis. Google Scholar acts as a bridge from the known quantity of Google to more advanced instruction required for Web of Science. Discussing the strengths and weaknesses of both databases is a good way to begin a dialog about when Google Scholar might be an appropriate tool 
for research and also allow librarians to make a stronger case for why other databases such as Web of Science need to be used as well.

For many of these same reasons, Google Scholar has a place in instruction at institutions that do not have access to Web of Science. Although many college and university

For instructing undergraduate students in the use of the "cited by" features, Google Scholar's lack of advanced search functions may actually be a boon. budgets cannot support subscriptions to Web of Science, undergraduate students often need access to citation searching or, at a minimum, need to learn how and when to use various citation features. Students can learn how to use the "cited by" feature with Google Scholar and at least some of the resulting sources will be available freely on the Web. As more and more libraries take advantage of open URL link-resolver technology in conjunction with Google Scholar, articles available online via library subscriptions will also be available to students.

Both databases are useful for graduate students or faculty who are following an article's or author's influence forward in time. Both databases retrieve a good number of unique items. ${ }^{29}$ The complementary nature of their formats and dates results in a more thorough search.

Google Scholar adds some non-periodical sources and more obscure or recent versions of publications in repositories, whereas Web of Science covers the prestigious peer-reviewed journals. (Though it must be noted that the very existence of Google Scholar, electronically published journals,

Because the nature and coverage of the Google Scholar database is not published, the researcher cannot know to what extent a thorough or complete search has
been accomplished. open access, and repositories are changing which journals have the most impact or prestige. ${ }^{30}$ ) Because the nature and coverage of the Google Scholar database is not published, the researcher cannot know to what extent a thorough or complete search has been accomplished. The ambiguity engendered by this incomplete research gestalt can be unsettling to the accomplished researcher. Graduate or faculty researchers doing complex bibliometric analysis will continue to benefit, however, from the advanced search functionality, controlled vocabulary, and known search domain of Web of Science.

The Web of Science remains a strong tool for citation searching and has continued to improve over time. Google Scholar should be moving out of beta mode soon and hopefully will continue to be refined as well. In April 2006, Microsoft launched Windows Live Academic Search, though it does not yet include citation features. Having highprofile companies like Thomson, Google, and Microsoft develop databases of scholarly information bodes well for researchers in the future. These powerful tools, combined with librarians' recommendations on when to use them, should make navigating the "Web of scholarship" even more exciting and productive. 
Robert Schroeder is reference librarian and coordinator of information literacy, Portland State University Library, Portland OR; he may be contacted via e-mail at: schroedr@pdx.edu.

\section{Notes}

1. Eugene Garfield, "Citation Indexes for Science: A New Dimension in Documentation through Association of Ideas," Science 122, 3159 (July 15, 1955): 108-11.

2. Richard K. Belew, "Scientific Impact Quantity and Quality: Analysis of Two Sources of Bibliographic Data," arXiv\#: CoRR/0504036 (April 11, 2005): 10, http:/ / arxiv.org/PS_ cache/cs / pdf/ 0504/ 0504036.pdf (accessed January 25, 2007).

3. Kathleen Bauer and Nisa Bakkalbasi, "An Examination of Citation Counts in a New Scholarly Communication Environment," D-Lib Magazine 11, 9 (September 2005), http:/ / www.dlib.org/dlib/september05/bauer/09bauer.html (accessed January 27, 2007).

4. Peter Jacso, "Peter Jacso: Google Scholar and The Scientist," http:/ / www2.hawaii. edu/ jacso/extra/gs/ (accessed January 27, 2007).

5. Jacso, "As We May Search-Comparison of Major Features of the Web of Science, Scopus, and Google Scholar Citation-based and Citation-enhanced Databases," Current Science 89, 9 (November 10, 2005): 1543, http:/ / www.ias.ac.in/currsci/nov102005/1537.pdf (accessed January 25, 2007).

6. Jacso, "Comparison and Analysis of the Citedness Scores in Web of Science and Google Scholar," in Digital Libraries: Implementing Strategies and Sharing Experiences, $8^{\text {th }}$ International Conference on Asian Digital Libraries, ICADL 2005, Bangkok, Thailand (Berlin, New York: Springer, 2005), 360-9.

7. Alireza Noruzi, "Google Scholar: The New Generation of Citation Indexes," LIBRI 55, 4 (2005): 170-80, http:/ / www.librijournal.org/pdf/2005-4pp170-180.pdf (accessed January 28, 2007).

8. Daniel Pauly and Konstantinos I. Stergiou, "Equivalence of Results from Two Citation Analyses: Thomson ISI's Citation Index and Google's Scholar Service," Ethics in Science and Environmental Politics (December 22, 2005), http:/ / www.int-res.com/articles/esep/2005/ E65.pdf (accessed January 27, 2007).

9. Nisa Bakkalbasi et al., “Three Options for Citation Tracking: Google Scholar, Scopus, and Web of Science," Biomedical Digital Libraries 3, 7 (June 29, 2006), http: / / www.bio-diglib. com/content/pdf/1742-5581-3-7.pdf (accessed January 27, 2007).

10. Kayvan Kousha and Mike Thelwall, "Google Scholar and Google Web/URL Citations: A Multi-Discipline Exploratory Analysis, " in Proceedings of the International Workshop on Webometrics, Informetrics and Scientometrics and Seventh COLLNET Meeting (Nancy, France, 2006), http:/ / eprints.rclis.org/ archive/ 00006416/01 / google.pdf (accessed January 28, 2007).

11. Kiduck Yang and Lokman I. Meho, "Citation Analysis: A Comparison of Google Scholar, Scopus, and Web of Science," in Proceedings 69th Annual Meeting of the American Society for Information Science and Technology (ASIST) 43, ed. Andrew Dillon and Andrew Grove (Austin, Texas, 2006), http:/ / eprints.rclis.org/archive/00008121/01/Yang_citation.pdf (accessed January 28, 2007).

12. Belew; 10. Jacso notes that although ISI has recently created a proceedings database, it is not yet part of the Web of Science nor does it have a cited reference feature. Jacso, "As We May Search," 1540.

13. Jacso, "Comparison and Analysis," 367.

14. Ibid.

15. Ibid.

16. Belew, 10; Bauer and Bakkalbasi, 5; Noruzi, 172; Yang, 10; and Bakkalbasi et al., 7.

17. Noruzi, 172; Yang, 10.

18. Bauer and Bakkalbasi, 3 .

19. Bauer and Bakkalbasi, 6; Jacso, "As We May Search," 1538. 
20. Noruzi, 174; Yang, 5; Jacso, "Peter Jacso: Google Scholar."

21. Bauer and Bakkalbasi, 3; Belew, 7; and Bakkalbasi et al., 7 .

22. Belew, 3, 6; Bauer and Bakkalbasi, 7 .

23. Bauer and Bakkalbasi, 4 .

24. Jacso, "Peter Jacso: Google Scholar."

25. Jacso, "As We May Search," 1539; Jacso, "Comparison and Analysis," 361.

26. Jacso, "As We May Search," 1539.

27. Jacso, "Comparison and Analysis," 361.

28. Ibid., 367.

29. Jacso, "As We May Search," 1543; Belew, 10.

30. For how open access is influencing the impact of articles, see The Open Citation Project, "The Effect of Open Access and Downloads ('Hits') on Citation Impact: A Bibliography of Studies," The Open Citation Project, http:/ / opcit.eprints.org/oacitation-biblio.html (accessed January 12, 2007). 